\title{
І.О. Тихонкова
}

канд. біол. наук,

старш. наук. співроб. Інституту молекулярної біології і генетики

НАН України,

керівник редакції журналу Biopolymers and Cell,

фахівець з наукометричних ресурсів та навчання Clarivate Analytics

e-mail: iryna.tykhonkova@clarivate.com

https://orcid.org/0000-0003-1115-3742

\section{РЕЦЕНЗУВАННЯ - НАРІЖНИЙ КАМІНЬ НАУКОВОЇ КОМУНІКАЦІЇ. МОЖЛИВОСТІ PUBLONS ДЛЯ НАУКОВЦЯ, ЖУРНАЛУ, АДМІНІСТРАТОРА}

https://doi.org/10.15407/akademperiodyka.391.085

Рецензування - обов'язковий процес, що має бути у наукового видання, проте часто можемо зустріти нерозуміння його функції та викривлені практики: друк без рецензії, вимога надіслати рецензію з рукописом. Окрім того, вічна проблема видання - знайти дійсно фахівців для рецензування певної публікації. Як правило, потужні видавництва та журнали $з$ історією мають напрацьовані бази рецензентів, але все частіше надходять роботи, виконані на межі дисциплін, і постає проблема, особливо для окремих видань: хто може дати експертну роботу такому дослідженню. База Publons створена у 2012 році, їі місія декларується як пришвидшення науки за рахунок сили рецензування. Це платформа для комунікації рецензентів і редакторів. У 2018 році була придбана компанією Clarivate Analytics, а 3 квітня 2019 року авторські профілі ResaercherID мігрували до Publons. Можливості ресурсу для науковців, рецензентів і видань розглянуто у статті.

Ключові слова: науковий журнал, рецензування, наукова комунікація, Publos, ResearcherID.

Наукові результати фіксуються публікацією в наукових виданнях, монографіях, патентах, кваліфікаційних роботах, виступах на конференціях, звітах тощо. Для розвитку науки важливі як площадка для періодичного обміну думками, чим із 1665 року за задумом Генрі Олдмана стали наукові видання $[1,2]$, так і перевірка результатів, що подаються на новизну, актуальність, доцільність, коректність, дотримання біоетичних процедур [3]. Схема публікаційного процесу відома, у виданнях можуть бути лише незначні варіації (рис. 1).

Подання роботи. Стаття може подаватися через автоматичні системи менеджменту журналу, наприклад OJS, ScholarOne тощо, у певному форматі із заповненням відповідних анкет, або автори 


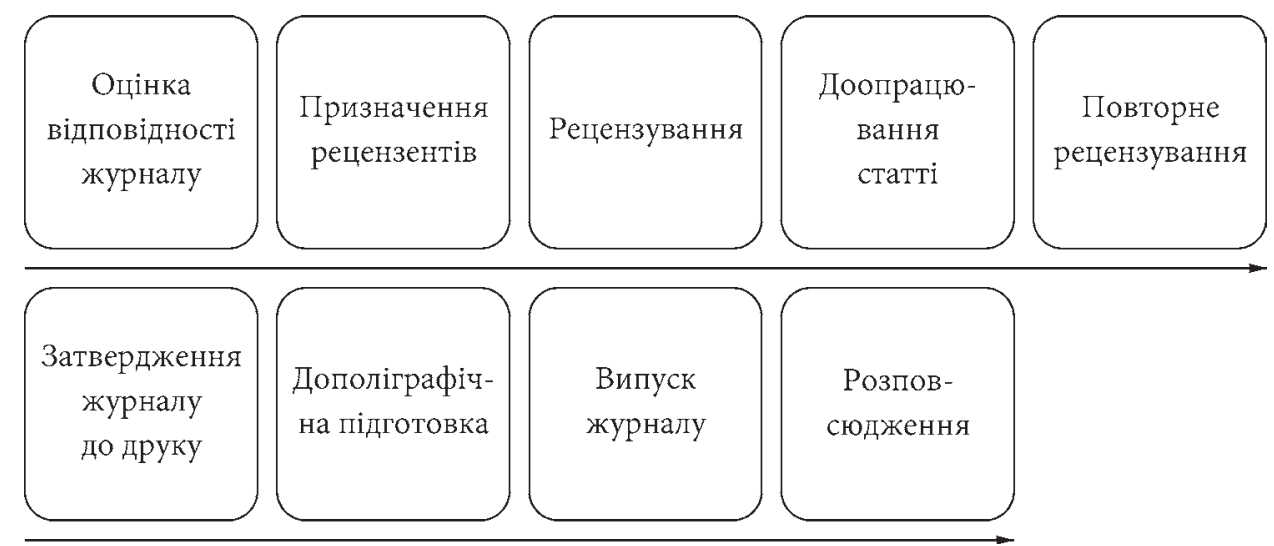

Puc. 1. Схема публікаційного процесу

надсилають необхідний пакет документів електронною, а інколи і звичайною поштою.

Відповідність. Далі перевіряється відповідність технічним критеріям: наявність усіх необхідних елементів публікації, коректність подання інформації про авторів, афіліації, відсутність плагіату, наявність декларації про відсутність конфлікту інтересів та, якщо цього вимагає бізнес-модель видання, - договір про передачу авторських прав. Редколегія або відповідальні за рубрику редактори оцінюють роботу на відповідність тематиці видання та чи зацікавить дана робота читацьку аудиторію, за позитивної відповіді обираються рецензенти.

Рецензування. Англійською Peer Review - оцінка колегами. Рецензенти - це фахівці, що працюють у даній галузі і мають власні публікації за темою $[4,5]$. Їм надсилається запрошення, а після отримання згоди - рукопис та бланк рецензії. Вирізняють відкрите та закрите рецензування. Відкрите охоплює рецензію неопублікованих та опублікованих матеріалів. Два основні види закритого рецензування у наукових виданнях - Single- та Doubleblind. В обох випадках автор не повинен знати, хто призначений рецензентом, а в останньому і рецензент не знає, роботу якого колективу рецензує, оскільки з манускрипту прибирається інформація про авторів та афіліації. Інколи практикується Triple blind review - коли і редактор не має доступу до інформації про авторів, оскільки робота анонімізується під час подання рукопису. Рецензенти задають зауваження у вигляді коментарів у тексті на окремому бланку та дають рекомендації: прийняти рукопис, чи прийняти після доопрацювання, чи потрібне суттєве доопрацювання, чи відхилити. Відповідальний редактор і відповідальний за рубрику, зважаючи на зауваження рецензентів, можуть або відхилити статтю, або відправити авторам на доопрацювання.

Конфлікт інтересів. Може бути результатом фінансової чи особистої конкуренції, інтелектуальної прихильності чи упередженості тощо. Може 
виникати в кожної ключової фігури журналу: автора, рецензента, редактора. Так, автори обов'язково мають повідомляти під час подання рукопису, особливо якщо це стосується біомедичних досліджень, про можливу фінансову або технічну допомогу, що проходить за рахунок, наприклад, фармацевтичних компаній. Рецензенти та члени редколегії повідомляють про можливий конфлікт інтересів у процесі рецензування роботи та відмовляються від рецензії певного рукопису. Зверніть увагу на ICMJE Recommendations:

http://www.icmje.org/recommendations/translations/russian2016.pdf

Конфіденційність. Редколегія та рецензенти не мають права розголошувати зміст рукопису до опублікування рукопису або якщо його відхилили. Рецензії не надаються стороннім організаціям чи особам, як виключення - уповноважені державні органи.

Доопрацювання статті. Якщо авторам запропонували доопрацювати статтю, вони мають додати відповідні зміни до тексту, відмітити їх, написати відповідь на кожен пункт зауваження. Або погодитись зі змінами і вказати, які правки було зроблено, або навести аргументовану відповідь, чому рекомендовані правки не будуть внесені. Виправлений варіант відправляється рецензентам, якщо вони погоджуються, то редколегія може затвердити статтю до друку, беручи до уваги дату подання статті до редакції чи можливу пріоритетність публікаціі. Рецензії зберігаються в редакціях.

Затвердження номера. Остаточне рішення щодо друку ухвалює редколегія. Для свого рішення вона може залучати додаткових фахівців, і тому інколи у статті може бути до семи рецензентів. Редколегія має право формувати спеціалізовані номери, запрошувати із тематичними оглядами авторів, формувати тематику видання, створення нових рубрик чи закриття тих, що вже втратили актуальність. Редколегія повинна забезпечувати якісне рецензування, дбати про дотримання академічної етики. Наприклад, у журналі можуть публікуватися роботи, де члени редколегії можуть бути співавторами, проте вести роботу щодо даної публікації (призначати рецензентів, брати участь у обговоренні статті та затвердженні іiі до номера) повинні інші члени редколегіі. Хочу зазначити, що у деяких виданнях кількість відхилених статей більше $90 \%$.

Дополіграфічна підготовка. На цьому етапі змістовні зміни до тексту чи малюнків неможливі, проте питання та невеликі зміни щодо тексту, рисунків чи таблиць враховуються. Верстка направляється авторам, вони перевіряють коректність відображення матеріалу, і лише за згодою авторів робота відправляється до друку.

Розповсюдження. Доступ до повного тексту, залежно від бізнес-моделі видання, може бути відкритий чи за передплатою. Передплата може бути як на паперові версії журналу, так і на доступ до електронних копій. Доступ до електронних копій може надаватися на фіксований проміжок часу або на необмежене користування. Повторне використання ілюстрацій або матеріалів авторами і читачами оговорюється у кожному конкретному випадку, умови описані на сайті видання. Для авторів важливо пам'ятати, що вони також 
можуть долучитись до розповсюдження інформації про свої публікації через створення та підтримку в актуальному стані профілів Publons (ResearcherID), Orcid [6], ResearchGate, Academia.Edu, Google Scholar, ScopusID тощо.

Однак чи має автор право на розміщення фінальної версії публікації залежить від правил видання, ознайомитися з ними варто на сайті або переглянути у http://www.sherpa.ac.uk/romeo/index.php

Необхідно зазначити, що індексування видання як спеціалізованими (MedLine, InSpec, Zoological Records), так і наукометричними (що містять реферативну частину статті і пристатейний перелік літератури) базами даних (Web of Science Core Collection, Scopus), збільшує видимість роботи науковця.

У вимогах, за якими відбирається видання до індексування, завжди буде пункт про наявність рецензування. У критеріях відбору до Web of Science Core Collection вказано: «Застосування процесу рецензування - це індикатор стандартів журналу, що свідчить про загальну якість, цілісність поданих досліджень та повноту бібліографічних елементів, особливо цитованих посилань».

Відповідно до наказу МОН від 15.01.2018 № 32 «Про затвердження Порядку формування Переліку наукових фахових видань України», «...забезпечення якісного незалежного рецензування поданих для публікації матеріалів вченими, які здійснюють дослідження за спеціальністю і мають за останні три роки не менше однієї публікації у виданнях, включених до Переліку, або закордонних виданнях, включених до Web of Science Core Collection та / або Scopus, або мають монографії чи розділи монографій, видані міжнародними видавництвами, що належать до категорій «А», «В» або «С» за класифікацією Research School for Socio-Economic and Natural Sciences of the Environment (SENSE); рецензії, підписані рецензентом звичайним або цифровим електронним підписом, мають зберігатися в редакції не менше трьох років».

Коли ж виникло рецензування? Які основні вимоги? Де шукати рецензентів? Чому вони не отримують за це плату? Як довго триває процес рецензування?

Рецензування наукових видань почалось із перших випусків одного 3 перших наукових журналів Philosophical Transactions of the Royal Society: peцензував статті редактор, засновник, спонсор і видавець журналу, секретар Королівського товариства Henry Oldenburg. Детальний аналіз розвитку рецензування $є$ у роботі [4], де зокрема, вказано про різні форми рецензування або їхню відсутність у деяких виданнях до середини XX століття. У журналі Lancet рецензування не було до 1976 року, тоді як у The British Medical Journal 3 кінця XIX століття публікації, що надійшли не від редакторів, надсилали на оцінку стороннім експертам.

На сьогодні, зважаючи на стрімке збільшення кількості науковців, видань, тиску установ та грантодавців, для вченого дуже важливо, щоб публікації були опубліковані в рецензованому виданні, тож першою експертною ланкою стають рецензенти. Проте традиційно робота рецензентів у виданнях не оплачується. Що ж спонукає науковців витрачати час та долучатися 
до рецензування? За результатами глобального дослідження, у якому взяли учать більше 11800 рецензентів у 2018 році (https://publons.com/community/ gspr\#open-elq-form-slider-DLGSPR), науковці погоджуються на рецензування, тому що:

- це частина моєї роботи як дослідника - 40,8 \%;

- я рецензую чиїсь роботи, а хтось рецензує мої - 35,1%; $32,9 \%$;

- хочу бути ознайомленим із найсвіжішими даними в моїй галузі -

- це забезпечення якості і цільності досліджень, опублікованих за моєю темою - 32,9\%;

- це волонтерська робота у моїй галузі / дослідженні - 17,5 \%;

- підвищення репутації важливо для кар'єри - 13,9 \%;

- це удосконалює мої навички письмового викладу - 13,5 \%;

- хочу побудувати відносини з журналом / редакторами - 11,9\%.

Однак знайти рецензента й отримати його згоду прорецензувати рукопис, на думку 75 \% редакторів, - це є найскладнішою роботою, і у 2017 році погоджувалися 1 із 2,4 запитів, тоді як 2013 року коефіцієнт був 1,9.

Та на кожному етапі рецензування можуть бути втрати: бо й ті рецензенти, що погодилися написати рецензію, можуть не зробити іiі, тому для отримання двох рецензій часто необхідно розіслати до 6-10 запитів.

70,6 \% рецензентів відхиляють запрошення через невідповідність статті їхній тематиці дослідження, 42 \% - через зайнятість. Середній час на написання рецензії - 5 годин, а середній час оформлення рецензії складає 16,4 днів. Проте цифри різняться за галузями знань, і в комп’ютерних науках процес рецензування проходить швидше. Науковці із розвинутих країн відповідають повільніше за колег із менш розвинутих країн. Середній розмір рецензії складає 477 слів, але із першої групи країн рецензії довші у порівнянні із регіонами, що розвиваються (528 до 250 слів відповідно).

Що оцінюють рецензенти:

Відповідність профілю видання

Чи зачікавить аудиторію журналу

Новизну, актуальність

Використання сучасних методів

Логічність викладення, обговорення, висновків

Статистичну обробку, біоетику

Оформлення наочних матеріалів

Грантову підтримку

Мову

Оформлення

Лimepamyру

А також наявність недоброчесних практик, зокрема плагіат та некоректне иитування джерел.

Для підвищення якості рецензування та зменшення витраченого на нього часу 88 \% опитуваних відмітили необхідність спеціалізованого навчання. 
На платформі Publons розміщено безкоштовний курс Publons Academy для рецензентів, що складається з десяти навчальних модулів із детальними поясненнями і рекомендаціями:

1. Вступ: наукова публікація.

2. Структура публікацій.

3. Оцінка методологіі.

4. Розділ з даними і матеріалами.

5. Опис результатів роботи.

6. Етичні аспекти.

7. Що очікує видання від рецензентів.

8. Робота з редактором.

9. Рецензування до публікації статті.

10. Рецензування опублікованих робіт.

Цей курс варто переглянути не лише тим науковцям, хто планує рецензувати роботи, але і тим, хто пише статті, щоб розуміти, на що звертатимуть увагу рецензенти.

Publons - це платформа, що складається з таких модулів (позначені жирним шрифтом вже працюють, інші будуть відкриті наприкінці 2019 року):

Researcher profiles

Publons Academy

Reviewer Recognition Service

Publons Reviewer Connect

Publons for Funders

Publons for Institutions

Інформація щодо Publons Academy зазначена вище. Researcher profiles. Publons створена у 2012 році, їі місія декларується як «speed up science by harnessing the power of peer review» - пришвидшення науки за рахунок сили рецензування. Інтеграція з основними видавничими системами та співпраця з відомими видавцями дала змогу сформувати систему, де науковці мають можливість демонструвати свою роботу як рецензенти. Технічно співпраця достатньо проста: журнал, що співпрацює з Publons, після фінальної рецензії у листі дякує за роботу та надсилає посилання, за яким у профілі науковця в Publons відображається, що він був рецензентом для певного видання. 3 квітня 2019 року відомий авторський профіль ResearcherID мігрував до Publons, тож тепер науковці, які мали ResearcherID, із тими саме логіном і паролем заходять до свого профілю на Publons, Web of Science та EndNote online, оскільки усі три ресурси поєднані.

Профіль автора на Publons містить інформацію про загальну кількість публікацій у профілі, кількість цитувань тих з них, що індексуються у Web of Science Core Collection, h-index (Індекс Гірша), та кількість підтверджених рецензій (рис. 2). Створення, підтримання, наповнення профілю Publons для авторів безкоштовно.

Додавати власні роботи можна, імпортувавши їх з Web of Science, у цьому випадку автоматично присвоюється номер ResearcherID. В Україні з 1 червня 


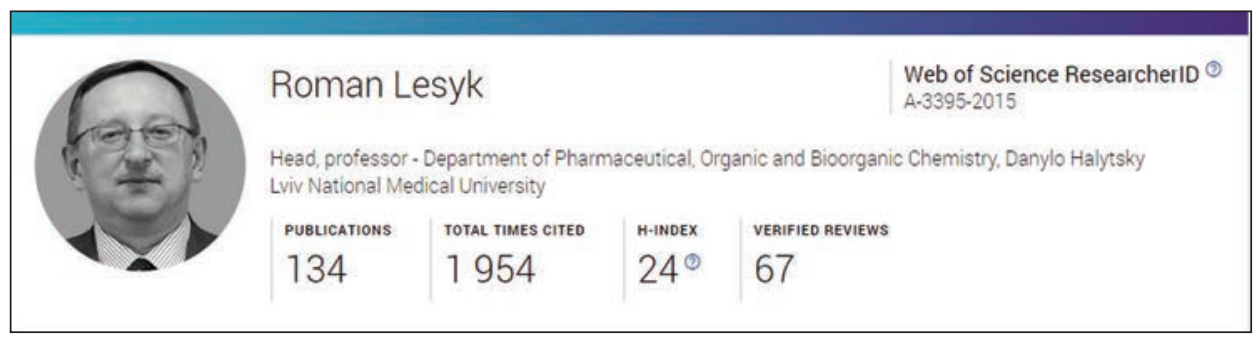

Puc. 2. Профіль науковця в Publons

2019 року за запитом МОН через Державну науково-технічні бібліотеку України діє національна передплата на Web of Science, тобто кожна бюджетна наукова або навчальна установа, що подала до ДНТБ відповідним чином оформлені заявки, отримала доступ: https://dntb.gov.ua/international-db-dntb.

Додавати статті можна таким чином: імпортувати записи з ORCID за doi або метаданими та через файли у ris-форматі.

Отже, науковець, розмістивши в своєму профілі інформацію про свої публікації та про рецензії для журналу, не лише підвищує свій рейтинг і демонструє свої здобутки, а й просуває наукове видання.

Компанія Clarivate Analytics, що є власником Web of Science, Publons, EndNote, на регулярній основі проводить безкоштовні вебінари та семінари українською та російською мовами про можливості платформи Web of Science, у тому числі ресурсів Journal Citation Reports Publons ResearcehrID, EndNote. Інформація на Facebook page Clarivate Analytics: https://www.facebook. com/WoS.Ukraianin/ та на: https://clarivate.ru/webinars.

Журналам на платній основі пропонуються два сервіси: Reviewer Recognition Service та Publons Reviewer Connect.

Publons Reviewer Connect використовує дані з Web of Science - більше 160 млн документів та 7 млн авторів, та дані Publons щодо авторів і рецензій, за резюме роботи обирає науковців, які мали схожі публікації, не мають конфліктів інтересів та не вказали, що зайняті у даний час.

Reviewer Recognition Service дає змогу завантажувати рецензії, налаштовано автоматизовану роботу із рецензентами та самооцінку рецензування видання.

Висновки. На сьогодні наукове видання не може бути без рецензування. Необхідно запрошувати для рецензування фахівців, які займаються саме тією вузькою тематикою, яку вказано у публікаціі.

Не варто залучати науковців, які відмітили неможливість роботи над рецензіями у даний час.

Необхідно зважати на дотримання видавничих стандартів, конфлікт інтересів, строки рецензування, конфіденційність. На жаль, досить часто рецензенти в нашій країні обмежуються виправленням стилістичних або граматичних помилок, що не приводить до покращення наукового рівня статті. 
Ще можна зустріти практику використання рецензій, які автори надсилають разом із рукописом, що не є прийнятним.

Навчання рецензентів та авторів може суттєво покращити їхню роботу, а реcypc Publons має модулі, що можуть бути корисними як авторам, так і виданням.

Традиційно хочеться подякувати організаторам щорічної конференції «Наукова періодика: традиції та інновації, яку 2019 року гостинно приймала Головна астрономічна обсерваторія НАН України, за можливість зустрітись із колегами, обговорити проблеми, що виникають у видань, послухати цікаві доповіді та обмінятися досвідом. І щира дяка усім співробітникам Видавничого дому «Академперіодика» НАН України за підтримку українських видань, корисні поради та розуміння особливостей і проблем, які часто виникають у процесі видання журналів.

\section{СПИСОК ВИКОРИСТАНИХ ДЖЕРЕЛ}

1. Garfield E. Refereeing and peer-review. 1. Opinion and conjecture on the effectiveness of refereeing. Current Content. 1986. 31. P. 3-11.

2. Benos D.J., Bashari E., Chaves J.M., Gaggar A., Kapoor N., La France M., Mans R., Mayhew D., McGowan S., Polter A., Qadri Y., Sarfare S., Schultz K., Splittgerber R., Stephenson J., Tower C., Walton R.G., Zotov A. The ups and downs of peer review. Adv Physiol Educ. 2007. 31. P. 145-152.

3. Тихонкова I.О. Джентльменський набір журналу. Що? Де? Скільки це нам коштуватиме і чи варто воно того? Наука Украӥни у світовому інформаційному просторі. Вип. 6. Київ, 2012. С. $61-67$.

4. Тихонкова I.О. Стратегія розвитку наукового видання. Наука України у світовому інформаційному просторі. Вип. 15. Київ, 2018. С. 16-27. https://doi.org/10.15407/ akademperiodyka.372.016

5. Enserink M. Scientific publishing: are you ready to become a number? Science. 2009. 323 (5922). P. 1662-1664. https://doi.org/10.1126/science.323.5922.1662

6. Haak L.L., Fenner M., Paglione L., Pentz E., Ratner H. ORCID: a system to uniquely identify researchers. Learned Publishing. 2012. 25 (4). P. 259-264.

Надійшла 13.08.2019

\section{REFERENCES}

1. Garfield, E. Refereeing and peer-review. 1. Opinion and conjecture on the effectiveness of refereeing. Current Content. 1986. (31): 3-11.

2. Benos, D.J., Bashari, E., Chaves, J.M., Gaggar, A., Kapoor, N., LaFrance, M., Mans, R., Mayhew, D., McGowan, S., Polter, A., Qadri, Y., Sarfare, S., Schultz, K., Splittgerber, R., Stephenson, J., Tower, C., Walton, R.G., Zotov, A. The ups and downs of peer review. Adv Physiol Educ. 2007. 31: 145-152.

3. Tykhonkova, I.O. Gentleman's journal set. What? Where? How much will it cost us and is it worth it? Science of Ukraine in the Global Information Space. 2012. 6: 61-67 [in Ukrainian].

4. Tykhonkova, I.O. Strategy of development of a scientific publication. Science of Ukraine in the Global Information Space. 2018. 15: 16-27 [in Ukrainian].

5. Enserink, M. Scientific publishing: are you ready to become a number? Science. 2009. 323 (5922): 1662-1664. https://doi.org/10.1126/science.323.5922.1662

6. Haak, L.L., Fenner, M., Paglione, L., Pentz, E., Ratner, H. ORCID: a system to uniquely identify researchers. Learned Publishing. 2012. 25 (4): 259-264. https://doi.org/10.1087/20120404 
I.O. Tykhonkova, $\mathrm{PhD}$ (Biol.)

Institute of Molecular Biology and Genetics of the NAS of Ukraine

Clarivate Analytics

\section{PEER REVIEW IS THE CORNERSTONE OF SCIENTIFIC COMMUNICATION. PUBLONS IS AN INSTRUMENT FOR SCIENTISTS, JOURNAL MANAGERS AND ADMINISTRATORS}

Peer review is an essential process for a scholarly publication. Unfortunately, this process is often misunderstood or improperly used, for example when authors are asked to supply a review of their proper work. In addition, the eternal problem of every journal editor or grant agency manager is to find experts for reviewing a particular publication or grant application. As a rule, established publishing houses and journals have their own databases of reviewers, but more and more papers are coming from a combination of disciplines; therefore, competent reviewers are particularly hard to find. Established in 2012, Publons has a mission to «speed up science by harnessing the power of peer review». It is a communication platform for reviewers and editors acquired by Clarivate Analytics in 2018, and since April 2019 ResearcherID author profiles were migrated into Publons. Publons opportunities for scientists, reviewers, and editors were presented during the last conference organized by Akademperiodyka and in this short communication.

Keywords: scientific journal, peer review, scientific communication, Publons, ResearcherID. 